This is an Accepted Manuscript of an article published by Taylor \& Francis in International Journal of Mathematical Education in Science and Technology on 19 Oct 2020, available online: https://doi.org/10.1080/0020739X.2020.1831091. 


\title{
Effects of a Successful Mathematics Classroom Framework on Students' Mathematics Self-Efficacy, Motivation, and Achievement: A Case Study with Freshmen Students at a University Foundation Programme in Kuwait.
}

"No potential conflict of interest was reported by the authors."

\begin{abstract}
Designed for this study as a conceptual framework comprising particular educational approaches and techniques for mathematics teaching and learning, the Successful Mathematics Classroom (SMC) aimed to promote college students' mathematics selfefficacy, motivation, and achievement. Through using a case study methodology, a range of tests and interviews, we investigated the effects of the SMC on a sample of 130 freshmen students from a mathematics foundation program in everyday classroom practice. The results showed a positive correlation between students' self-efficacy and achievement, as well as their motivation and achievement. The results further revealed that there was a positive impact of using the SMC framework on students' mathematics self-efficacy, motivation, and performance. The elements with most impact were teacher's teaching methodology, group work, teacher's attitude, and gamification. Further research is recommended to examine the effects of SMC in different education settings, different students, teaching styles, and larger sample sizes.
\end{abstract}

Keywords: self-efficacy; motivation; achievement, mathematics learning

\section{Introduction}

For the past 30 years, Kuwait's educational leaders have been putting efforts into improving their educational systems. Still, freshmen college students in Kuwait continued to perform in lower percentiles in the mathematics entrance exams at different universities for the past 5 years. Soliman and Hilal's (2016) research stressed the weak mathematics knowledge that students have when they apply for the Kuwait University entrance exams (26\% success rate), raising concerns about all levels of the state education system. 
Gulf University for Science and Technology (GUST), in which this research took place, is one of the universities with poor success rates in mathematics entrance exams. When students apply to join GUST for their college studies, they are requested to take the university's entrance examination (Accuplacer) and are assigned to courses either at the foundation or academic programs according to their Accuplacer scores in the Arithmetic and Algebra tests. GUST statistics (based on Registration's records) for the past five academic years revealed that an average of $26 \%$ of the total number of students applying passed the Accuplacer examination and proceeded directly to academic courses, while $74 \%$ of the students were weaker in their mathematics knowledge and were required to take the mathematics foundation courses at the Mathematics Foundation Unit (MFU). The researcher and other teachers at the foundation unit noticed that students who join the MFU lack not only knowledge but also self-efficacy and motivation to learn and progress in mathematics. This study, therefore, was designed to explore how to improve students' self-efficacy and motivation and ultimately improve their performance and achievement in mathematics.

To achieve this aim, the researcher used the Successful Mathematics Classroom (SMC) framework, which consisted of specific educational approaches (e.g., ideas and beliefs about teaching) and techniques (e.g., activities and procedures for teaching) recommended by the literature as suitable for improving any, or all three, of the study's variables (self-efficacy, motivation, and achievement).

\section{Literature Review}

\section{Students' Self-efficacy and Mathematics Achievement}

Bandura (1977) defined self-efficacy as the individual's belief in their capability to organize and perform the actions needed to achieve certain tasks. Also, Bong (1999) defined self-efficacy as “one's convictions about performing a given academic task at a designated level” (1999, p. 315). If individuals are able to recognize their self-efficacy beliefs and 
understand the results of their actions, they can use the meaning of their results to improve their self-efficacy beliefs and their related capabilities. Other researchers, such as Chemers, $\mathrm{Hu}$, and Garcia (2001) and Akinsola and Awofala (2008), maintained that self-efficacy is partly about self-judgments that may support someone to successfully complete a certain tasks at a particular academic level in a school or college, which, in turn, may be the reason for their success or failure in future mathematics activities.

Researchers such as Hackett (1985), Pajares and Miller (1994), and Siegle and McCoach (2007) explained that there is a positive relationship between mathematics selfefficacy and students' academic achievement. Also, Siegle and McCoach (2007), Hoffman (2010), and Kitsantas, Cheema, and Ware (2011) emphasized that certain teacher's talk and feedback can have a significant effect on students' perceptions of their own effort and ability. This also suggests that improving self-efficacy is an important factor in helping to improve mathematics performance.

\section{Students' Motivation and Mathematics Achievement}

Guay et al. (2010) defined motivation as "the reasons underlying behaviour" (2010, p. 712). Also, Gredler, Broussard, and Garrison (2004) defined motivation as "the attribute that moves us to do or not to do something”. In Education, particularly for learning, it is agreed that motivational beliefs are essential elements in students' academic success and that motivation and academic achievement have direct links and that the former affects the latter (Skaalvik \& Valas, 1999; Robbins et al., 2006; Anderman \& Wolters, 2006; Fan \& Wolters, 2014; Ernest, 2011). The more motivated the students are, the more involved and engaged with their learning they are, and the more interested and determined they will be to complete the task they are engaged in. More effort and commitment increase the possibility of success and consequently their self-efficacy, which then reinforces motivation and further engagement with learning and learning tasks (Fan \& Wolters, 2014; Ernest, 2011). 
Kim and Keller (2010) and Fan and Wolters (2014) indicated that "when students are genuinely interested in the tasks involved in learning mathematics and English, they tend to expect themselves to graduate from high school, and attend college". In other words, the higher the students' motivation towards learning mathematics, the more they will be encouraged to attend college, and the more successful they will be in their chosen discipline.

There are two types of motivation: extrinsic and intrinsic. Sansone and Harackiewicz (2000) defined extrinsic motivation as a source of the external motivation to the person. They explained that extrinsic motivation can emerge when motivation is based on something extrinsic to the activity, and when something extrinsic occurs to the person. They also defined intrinsic motivation as the motivation resulting from enjoying an activity or considering it as an opportunity to explore, learn, and actualize the individual's potentials.

\section{How to Improve Students' Self-efficacy, Motivation, and Achievement in Mathematics?}

The literature from the fields of mathematics education (e.g., Mason, 2002; Martin \& Towers, 2015; Rowe, 2001; Usher, 2009; Wegerif et al., 2017) and educational psychology (e.g., Fan \& Wolters, 2014; Pajares \& Miller, 1994; Wigfield \& Eccles, 2000; Williams \& Williams, 2010; Van Dinther, Dochy \& Segers, 2011; Wyatt, 2010; Mitcham et al., 2012; Duman, \& Özçelik, 2018; Louth \& Jamieson-Proctor, 2019; Çelik, 2019; Damrongpanit, 2019) suggests that particular educational approaches and techniques may have a positive impact on students' performance and achievement through improving either their selfefficacy or motivation. The approaches and techniques that were identified from the literature as beneficial for the purpose of this study were: (i) group work, (ii) gamification, (iii) revision notes, (iv) small boards, (v) correcting students' own errors, (vi) teacher's teaching methodology, (vii) teacher's attitude, (viii) bonus marks, and (ix) online interactive educational platform. These approaches and techniques constituted the nine key elements, 
which formed the basis of the SMC framework, as illustrated in Figure 1. The SMC became the conceptual framework for this study.

\section{Figure 1}

SMC: The Conceptual Framework for the Study
1) Group Work
2) Gamification
3) Revision Notes
4) Small boards
5) Correcting the Students'
Own Errors
6) Teacher's Teaching
Methodology
7) Teacher's attitude
8) Bonus marks
9) Online Interactive
Educational Platform

1) Self-efficacy

2) Motivation
Mathematics Achievement

The following paragraphs explain each of the nine elements (the basis of the SMC) in the context of the reviewed literature and this particular research, and their relationship with students' self-efficacy and motivation (the core of the SMC), and consequently achievement and progress (the ultimate goal of the SMC).

Group work is a major approach of the (SMC) framework. Previous research reported a positive impact on students' learning, understanding, and motivation (Steinberg \&Vinjamuri, 2014; Martin \& Towers, 2015; Wegerif et al., 2017), and a positive influence on their self-efficacy (Wyatt, 2010; Mitcham et al., 2012; Chiriac, Rosander, \& Frykedal, 2019; Kopparla \& Goldsby, 2019), especially when students learn how to work and think together as a group (Wegerif et al., 2017). Chambers and Timlin (2013) provided some detail about 
using group work. They recommended dividing them into groups of four to six members while keeping the same number of members in each group. They also recommended that each group should be assigned a task to accomplish and then reassign high achievers into different groups to have an expert in each group. Also, they encouraged teachers to rotate group members around other groups in order to spread the knowledge. This can allow students to have creative discussions and improve their learning skills.

Gamification is an intrinsic motivation approach and may be part of group work. It consists of playing educational games as a learning tool that can provide the students with instant feedback, create engagement among the students, improve students' attendance rates, boost learning productivity, increase learning retention, encourage students to spend more time learning, and make learning seem fun (Topîrceanu, 2017). Also, using gamification in the classroom can produce a positive impact on students' learning, motivation, and understanding (Cruickshank \& Telfer, 1980; Rowe, 2001; Lazarides, Buchholz, \& Rubach, 2017; Topîrceanu, 2017) and on students' self-efficacy as well (Van Dinther, Dochy, \& Segers (2011); Gani, 2019; Louth \& Jamieson-Proctor, 2019; Yeh et al., 2019).

Revision notes in the context of SMC means encouraging and guiding students to revisit and revise the taught material and maintain an organized record of their revision notes. The teacher models to the whole class how this educational technique can be used (e.g., by providing sample questions that can help students summarize what they learned from a specific learning block). Research has found that this technique for teaching and learning has been found to show "Activation and acquisition of knowledge; - Formation of habits; Development of intellectual processes; - Review and assessment of skills taught" (Lupu, 2013, p. 1673). Also, it has shown to improve students' motivation and understanding (Lupu, 2013). Using revision notes was employed in this study among a combination of methods, 
components of courses, and practice learning methods, all of which can raise students' selfefficacy (Dinther, Dochy, \& Segers, 2011).

Small boards is another teaching technique that can be used for a quick formative assessment and for aiding students' learning by linking previously taught objectives to new objectives. Implementing in-class activities has shown a positive impact on students' learning and motivation (Hagger et al., 2016). Using the small boards can assist students in modeling parts or steps of the solution when engaged in problem-solving (Schoenfeld, 1992). In addition, it was used in this study among a combination of methods, components of courses, and practice learning methods which can raise students' self-efficacy (Dinther, Dochy, \& Segers, 2011).

Correcting students' own errors can be used to engage students in the process of thinking about their own thinking and understanding; a higher-order thinking skill linked to metacognition and self-knowledge as introduced by Flavell (1976). Research has reported benefits when students engage in such metacognitive activities, including improved students' understanding and motivation for learning (Kazemi and Stipek, 2001; Swan, 2005), as well as improved self-efficacy (Duman \& Özçelik, 2018; Louth \& Jamieson-Proctor, 2019; Peranginangin, Saragih, \& Siagian, 2019; Masitoh \& Prasetyawan, 2020; Maulidia, Saminan, \& Abidin, 2020; Fitriani et al., 2020).

Teacher's teaching methodology is another major element of the SMC model. It is about using different pedagogic teaching techniques, preparing active and purposeful questions and activities to be used while teaching. It is about using techniques to respond to students' learning needs and interests. Not only teacher's teaching methodology offers different techniques while questioning the students, but also, receives a variety of responsive learning strategies from the students, positive reaction between the students and teacher, fulfillment of students' needs for understanding, and improvement in students' mathematics 
learning, understanding, and motivation in the classroom (Barnes, 2005; Peled \& Segalis, 2005). It has also shown to improve students' self-efficacy (Brookfield, 2011; Çelik, 2019; Damrongpanit, 2019; Hamurcu \& Canbulat, 2019).

Teacher's attitude towards teaching mathematics and supporting students' learning is considered a factor that can influence positively or negatively students' academic progress. More specifically, the literature on the role of effect and motivation in mathematics learning suggests that teachers' positive attitude can improve students' motivation (Fan \& Wolters, 2014) and their self-efficacy (Ünlü, Avcu \& Avcu, 2010; Gudek, 2019; Engin, 2020; Fadhila, Ridlo, \& Indriyanti, 2020; Wahyudiati \& Rohaeti, 2020). Also, Teacher's attitude can motivate the students to sense the emotional and warm support in class and may assist them to regulate their academic learning skills and understanding (Sokol, Gozdek, \& Figurska, 2015).

Working hard to gain bonus marks is considered an important extrinsic motivational approach for the students as it helps to improve the students' learning skills (Miendlarzewska, Bavelier, and Schwartz, 2016). Using bonus marks improves students' motivation and selfefficacy (Stirin Tzur, Ganzach, \& Pazy, 2016; Park \& Yang, 2019; Zhang, Zhang, Liu, \& Du, 2019).

The use of an online interactive educational platform_has been discussed by different researchers, such as Handal and Herrington (2003) and Hargreaves et al. (2004). They discussed the important features and categories of computer-based learning in mathematics education. An online interactive platform can include a variety of the features that could influence students' mathematical learning through the use of approaches such as tutorials, hypermedia, drills, simulations, games, alerting tools and notices of late submission, openended questions and learning environments, multimedia videos explaining each objective, and web-based learning (Handal \& Herrington, 2003). This means, using an online 
interactive platform not only allows the students to practice what they learnt in class, but also could assist them in organizing and operating their conceptual knowledge (Banerjee \& Subramaniam, 2012; Soliman \& Hilal, 2016; Handal \& Herrington, 2003). Moreover, using an online interactive platform, it may offer immediate feedback and motivating comments that can improve students' learning skills, extrinsic motivation, since they gained grades for completing their online homework, achievement (Handal \& Herrington, 2003), and selfefficacy (Hall, 2019; Nordlöf, Hallström, \& Höst, 2019; O'Neil \& Krause, 2019; Bakar, Maat, \& Rosli, 2020).

The approaches and techniques presented as elements of the SMC were implemented in practice and critically examined to determine their effects and find the answers to the following research questions.

\section{Research questions}

- Is there any relationship between self-efficacy and students' mathematics achievement?

- Is there any relationship between motivation and students' mathematics achievement?

- What features within the framework promoted improved students' self-efficacy and motivation?

\section{Methodology}

The researcher in this study considered the use of the case study methodology to focus on individual students' changes in their mathematics self-efficacy, motivation, and achievement. The case study approach could provide detailed analysis in a specific field case that may include participant observation and process-tracking (Yin, 2014).

\section{Participants In The Study}

Two student cohorts were used in the study, all the students undertaking the Intermediate Algebra (Math096) course. The first cohort of student sample and data collection took place in the Spring 2017 semester. The second cohort and data collection took 
place in the Fall 2018 semester. The first cohort included groups (G1 to G4). The second cohort of student sample included groups (G5 to G8). The groups (classes) were assigned as a regular teaching load by the university registrar's office and MFU director and coordinator.

The researcher gained the 'Institutional Review Board' (IRB) approval from (name was removed for the peer review) administration and MFU director. The students voluntarily gave informed consent and were given the choice to keep a copy. The participants had the freedom to withdraw from participating in the study at any time during the study. Lastly, the researcher assured the participating students that their information will be treated confidentially.

\section{Design of the Study}

\section{Implementing the SMC}

This study required the implementation of the elements of the SMC framework approaches and the investigation of their impact on students' self-efficacy, motivation, and achievement. The teacher in this study was the researcher, and therefore all the necessary measures were taken to avoid a biased approach.

The researcher started implementing the SMC framework after the first one or two days of the course. Before implementing any change, the researcher discussed with the students what was going to happen in the classroom and how to organize their study time daily in school and at home (e.g., doing their online homework or reviewing the taught materials). The changes involved students' working style and teacher's teaching methodology as follows.

The students were divided into groups of 4 or 5 students, where one high achiever was involved in each group. The students were asked to discuss their tasks and possible solutions within their group and with the teacher, who was circulating in the class, monitoring the group work and supporting when necessary. One group representative was sharing the 
solution on the board with the teacher's assistance. The teacher encouraged discussions on exploring other possible methods to solve the same problem. The high achievers were rotating every day among different groups, and the teacher was checking to ensure that they were not solving the problems for their group members.

Once a week, during the last ten minutes of class, the students were playing Kahoot. During this play-based learning, the students were able to use their mobile phones while answering each Kahoot question. The students with the top ten highest scores were rewarded with one bonus mark added on their weekly quiz. Also, once a week, students were playing the puzzle sheet in groups. The first two groups completing the puzzle were rewarded one bonus mark added to their weekly quiz.

The small boards were used three days a week as the students were answering questions that were taught the previous day. The students were encouraged to discuss the answer with their near classmates and share their answers immediately out loud using their boards. The teacher was asking the whole class if each answer is right or wrong and why. After leaving class, the students were requested to complete their online homework using PEARSON MyMathLab. The program consisted of different practice problems of the taught materials and features that helped students revisit and test their learning. In addition to this, at the end of each chapter, the teacher was starting the class by asking the students five or six major questions that summarized the chapter. The students were working on those questions in groups and presenting their answers on the classroom board. The students used those questions as revision notes to prepare for their tests.

After the first week of the course, the teacher started assigning office hours with students whose scores were below $70 \%$ in their weekly quizzes every week. This allowed the teacher to discuss weekly progress with the students individually, clarify their understanding 
status, organize their studying skills, help them realize their capability to understand the course materials and to motivate them to work hard and pass the course.

For the duration of the implementation, the teacher/researcher maintained her enthusiasm in teaching and supporting students' mathematics learning, as a class and individually, and her positive attitude towards the subject.

\section{Instruments Used in the Study,their Validity and Reliability Background}

\section{Questionnaire}

The background questionnaire was designed to gain information about students' mathematics background and the courses they had taken in high school or at college as shown in appendix A. The questionnaire was used to categorize the students when analyzing their data.

\section{Self-efficacy Questionnaire}

This questionnaire was a 5-point Likert self-efficacy scale questionnaire that consisted of 14 questions as shown in Appendix B. The questions were similar to those used by previous research to measure self-efficacy such as [Pintrich (1991); Rahimi \& Abedini, (2009); Liu \& Koirala, (2009); Ferla, Valcke, \& Cai, (2009); Zimmermann, Bescherer, \& Spannagel, (2011); Cheng, (2001)]. Internal consistency was checked using Cronbach's Alpha test, which showed acceptable reliability (.727) of the questionnaire as shown in Table 1.

\section{Table 1}

The results of testing the internal consistency of the self-efficacy questionnaire using Cronbach's Alpha.

\section{Reliability Statistics}




\begin{tabular}{|c|c|r|}
\hline $\begin{array}{c}\text { Cronbach's } \\
\text { Alpha }\end{array}$ & $\begin{array}{c}\text { Cronbach's } \\
\text { Alpha Based } \\
\text { on } \\
\text { Standardized } \\
\text { Items }\end{array}$ & \\
\hline .728 & .727 & N of Items \\
\hline
\end{tabular}

The Cronbach's Alpha value for using the self-efficacy questionnaire is $0.727<1$. This shows there is high consistency between the self-efficacy questionnaire elements and that it is reliable.

\section{Motivation Questionnaire}

This questionnaire was a 5-point Likert motivation scale questionnaire that consisted of 10 questions as shown in Appendix C. The questions were similar to those used by previous research to measure motivation such as [Pintrich (1991); Zerpa, Hachey, Barneveld, \& Simon, (2011); Duda \& Nicholls, (1992); Githua \& Mwangi, (2003); Sundre, Barry, Gynnild, \& Ostgard, (2012)]. Also, Cronbach's Alpha was used to indicate the inter-item correlations. Internal consistency was checked using Cronbach's Alpha test, which showed acceptable reliability (.727) of the questionnaire as shown in Table 2.

\section{Table 2}

The results of testing the internal consistency of the motivation questionnaire using Cronbach's Alpha.

\begin{tabular}{|c|c|r|}
\hline \multicolumn{3}{|c|}{ Reliability Statistics } \\
\hline & Cronbach's & \\
Alpha Based & \\
on & \\
Cronbach's & Standardized & \\
\hline .748 & Items & N of Items \\
\hline \multicolumn{2}{|c|}{.736} & 4 \\
\hline
\end{tabular}


The Cronbach's Alpha value for using the motivation questionnaire is $0.736<1$. This shows that there is high consistency between the motivation questionnaire elements and that the questionnaire is reliable.

\section{Achievement Tests and Level Quiz}

The tests used in the study were all standardized achievement tests designed by MFU teachers and approved by the university department. The level quiz was designed by the researcher using a previously learned curriculum in a previously taught course Math 095.

\section{Semi-Structured Interviews}

The interview consisted of eight open-ended questions that discussed every element in the SMC framework and their influence on students' achievement if any. Twenty-five students volunteered to be interviewed at the end of the course. The students were selected based on their willingness to be interviewed. The volunteered students were divided into three categories; high, middle, and low achieving students. The ethical points related to the study were stated to each student before starting the interview to provide them with the proper arrangements to make them feel at ease during the interview. Students were assured confidentiality and anonymity. The names used in this study are nicknames and do not present any real identity of any of the volunteer students.

\section{The Stages of the Study}

The study was divided into four stages as follows:

\section{Stage 0 (The First Two Days of the Course):}

Students were asked to answer the background questionnaire as shown in Appendix A. Also, they were asked to complete the self-efficacy and motivation questionnaires as shown in appendices B and C, and the level quiz. The researcher started implementing the elements of SMC.

\section{Stage 1 (One Month After the Start of the Course):}


Students were asked to complete the self-efficacy and motivation questionnaires.

Also, they answered Test 1 . The researcher continued to use the SMC framework elements for the second month.

\section{Stage 2 (Two Months After the Start of the Course):}

Students were asked to complete the self-efficacy and motivation questionnaires, and Test 2. The researcher continued to use the SMC framework approaches for the rest of the semester.

\section{Stage 3 (Last Week of the Course):}

Students were asked to complete the self-efficacy and motivation questionnaires, and Test 4 (final exam). Also, the students from both cohorts were asked to be interviewed at the end of the course. The interviews were transcribed and coded to find the study themes and confirm the SMC framework elements.

\section{Findings of the Study}

\section{Students' Self-efficacy}

This section discusses the changes which occurred in students' self-efficacy from stages 0 to 3 with self-efficacy being scored out of 70 . Table 3 and Figures 2 show selfefficacy changes during the study. 
Table 3

Students' self-efficacy questionnaire medians at each stage of the course.

\begin{tabular}{|c|c|c|c|c|c|c|c|c|c|}
\hline & G1 & G2 & G3 & G4 & G5 & G6 & G7 & G8 & $\begin{array}{c}\text { Median for } \\
\text { total } \\
\text { students }\end{array}$ \\
\hline Stage 0 & 24.0 & 20.5 & 27.5 & 21.0 & 18.0 & 22.0 & 22.5 & 20.5 & 21.0 \\
\hline Stage 1 & 38.5 & 37.5 & 42.5 & 37.5 & 36.0 & 38.5 & 38.0 & 38.0 & 38.0 \\
\hline $\begin{array}{c}\text { Percentage } \\
\text { Increase From } \\
\text { Stage } 0 \text { to } 1\end{array}$ & 60.4 & 82.9 & 54.5 & 78.6 & 100.0 & 75.0 & 68.9 & 85.4 & 81.0 \\
\hline Stage 2 & 65.0 & 59.0 & 54.0 & 54.5 & 50.0 & 55.0 & 56.5 & 50.5 & 54.0 \\
\hline $\begin{array}{c}\text { Percentage } \\
\text { Increase From } \\
\text { Stage } 1 \text { to } 2 \\
\end{array}$ & 68.8 & 57.3 & 27.1 & 45.3 & 38.9 & 42.9 & 48.7 & 32.9 & 42.1 \\
\hline Stage 3 & 66.0 & 65.5 & 65.0 & 64.0 & 65.0 & 67.5 & 66.0 & 67.0 & 66 \\
\hline $\begin{array}{c}\text { Percentage } \\
\text { Increase From } \\
\text { Stage } 2 \text { to } 3\end{array}$ & 1.5 & 11.0 & 20.4 & 17.4 & 30.0 & 22.7 & 16.8 & 32.7 & 22.2 \\
\hline $\begin{array}{c}\text { Percentage } \\
\text { Increase From } \\
\text { Stage } 0 \text { to } 3\end{array}$ & 175 & 219.5 & 136.4 & 204.8 & 261.1 & 206.8 & 193.3 & 226.8 & 214.3 \\
\hline
\end{tabular}




\section{Figure 2}

Self-efficacy boxplots at each stage.

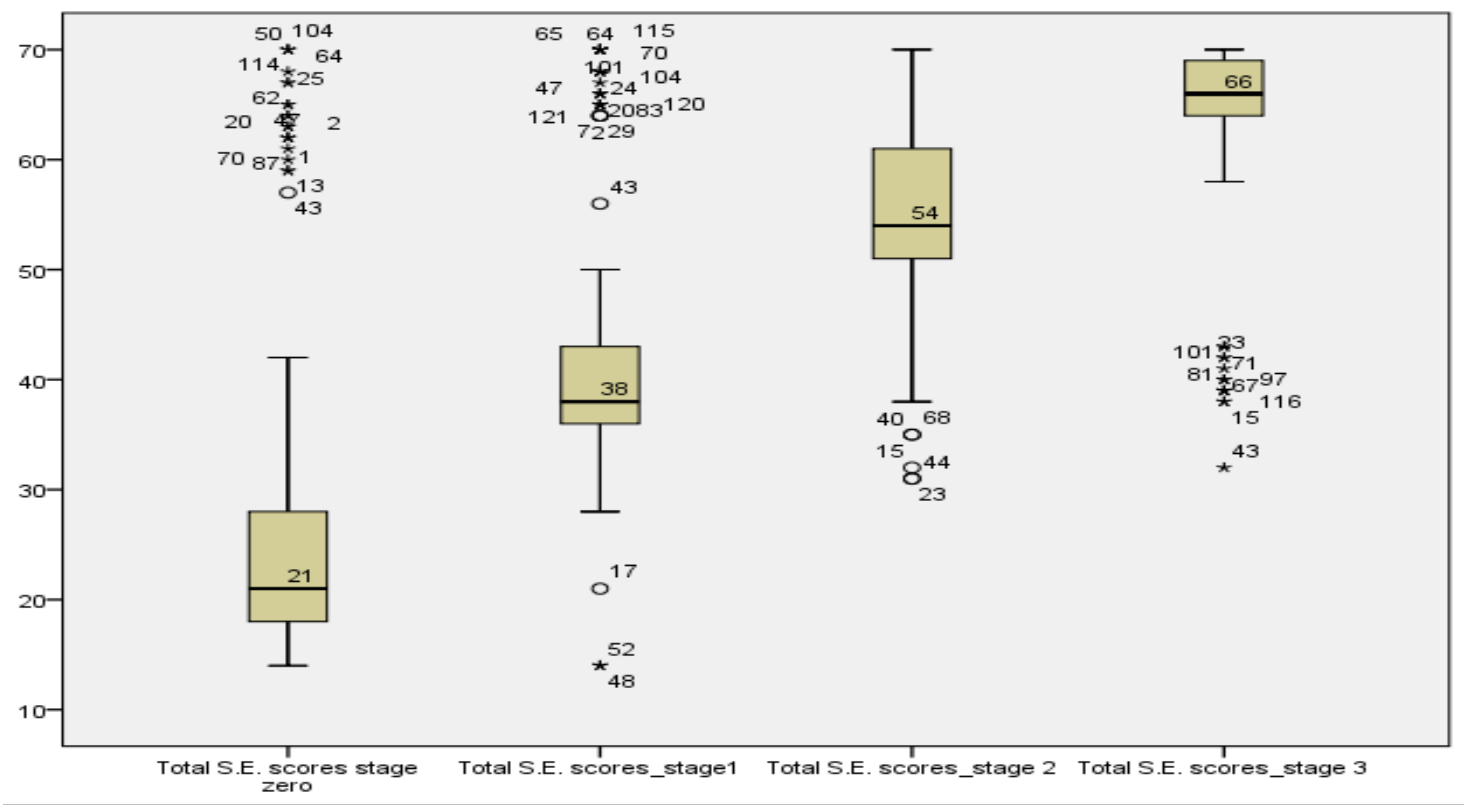

It can be seen that students started with low self-efficacy levels at the start of the course but gradually improved from stages 0 to 3. Also, the range of the box-plots decreased during the study, starting with wide ranges (stage 0 and 1), then decreased ranges at stage 2 and 3. This might be an indicator that SMC positively influenced students' self-efficacy during the course.

\section{Student's Motivation}

Table 4 and figures 3 show the motivation changes during the study. 
Table 4 The motivation changes during the study.

\begin{tabular}{|c|c|c|c|c|c|c|c|c|c|}
\hline & G1 & G2 & G3 & G4 & G5 & G6 & G7 & G8 & $\begin{array}{c}\text { Median for } \\
\text { total students }\end{array}$ \\
\hline Stage 0 & 17.0 & 14.0 & 19.5 & 15.0 & 13.0 & 14.5 & 15.5 & 15.0 & 15.0 \\
\hline Stage 1 & 31.5 & 33.5 & 28.5 & 26.5 & 26.0 & 27.0 & 26.5 & 26.5 & 27.0 \\
\hline $\begin{array}{c}\text { Percentage Increase } \\
\text { From Stage 0 to 1 }\end{array}$ & 85.3 & 139.3 & 46.2 & 76.7 & 100.0 & 86.2 & 71.0 & 76.7 & 80.0 \\
\hline Stage 2 & 45.0 & 43.5 & 39.5 & 39.5 & 36.0 & 40.5 & 44.0 & 35.5 & 39.0 \\
\hline $\begin{array}{c}\text { Percentage Increase } \\
\text { From Stage 1 to 2 }\end{array}$ & 42.9 & 29.9 & 38.6 & 49.1 & 38.5 & 50.0 & 66.0 & 34.0 & 44.4 \\
\hline \begin{tabular}{c} 
Stage 3 \\
\hline
\end{tabular} & 47.0 & 47.5 & 47.0 & 46.0 & 46.0 & 47.0 & 46.5 & 48.0 & 47.0 \\
\hline $\begin{array}{c}\text { Percentage Increase } \\
\text { From Stage 2 to 3 }\end{array}$ & 4.4 & 9.2 & 19.0 & 16.5 & 27.8 & 16.0 & 5.7 & 35.2 & 20.5 \\
\hline $\begin{array}{c}\text { Percentage Increase } \\
\text { From Stage 0 to 3 }\end{array}$ & 176.5 & 239.3 & 141.0 & 206.7 & 253.8 & 224.1 & 200.0 & 220.0 & 213.3 \\
\hline
\end{tabular}


Table 4 and figure 3 show that the students' motivation for all participating groups gradually improved from stages 0 to 3 . This might be another indicator that SMC positively influenced the students' motivation levels during the course.

\section{Figure 3}

Motivation boxplots for the total score for all groups of students participating in the study for all stages.

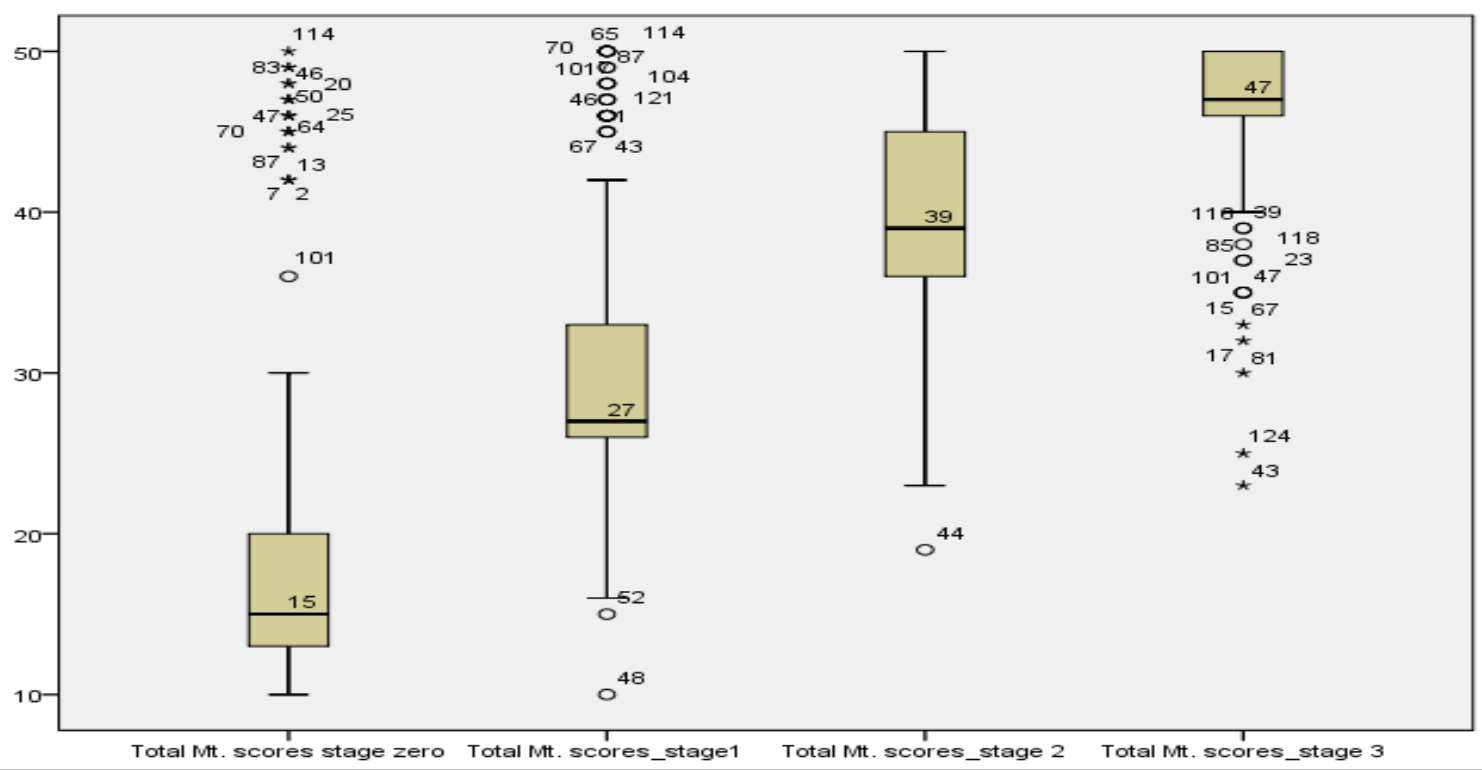

\section{Level Quiz and Tests}

This section reports on the students' mathematics knowledge revealed through students' test scores at each stage of the course in percentages. These scores are shown in Table 5 and Figure 4.

Table 5

Students' test scores (mean in percentage) at each stage of the course.

\begin{tabular}{|c|c|c|c|c|c|c|c|c|c|}
\hline $\begin{array}{c}\text { Group } \\
\text { Number }\end{array}$ & G1 & G2 & G3 & G4 & G5 & G6 & G7 & G8 & $\begin{array}{c}\text { Mean for } \\
\text { all Groups } \\
\text { Together }\end{array}$ \\
\hline
\end{tabular}




\begin{tabular}{|c|c|c|c|c|c|c|c|c|c|}
\hline $\begin{array}{c}\text { Mean (\%) } \\
\text { for Stage 0 }\end{array}$ & 48 & 41 & 46 & 46 & 30.6 & 28 & 39.5 & 27 & $\mathbf{3 8 . 6}$ \\
\hline $\begin{array}{c}\text { Mean (\%) } \\
\text { for Stage 1 }\end{array}$ & 74 & 67 & 62 & 73.5 & 63.5 & 67.3 & 75 & 58 & $\mathbf{6 7 . 6}$ \\
\hline $\begin{array}{c}\text { Percentage } \\
\text { Increase } \\
\text { From Stage } \\
\text { 0 to 1 }\end{array}$ & $\mathbf{5 4 . 2}$ & $\mathbf{6 3 . 4}$ & $\mathbf{3 4 . 8}$ & $\mathbf{5 9 . 8}$ & $\mathbf{1 0 7 . 5}$ & $\mathbf{1 4 0 . 4}$ & $\mathbf{8 9 . 9}$ & $\mathbf{1 1 4 . 8}$ & $\mathbf{8 3 . 1}$ \\
\hline $\begin{array}{c}\text { Mean (\%) } \\
\text { for Stage 2 }\end{array}$ & 87.8 & 69.3 & 71.8 & 73.9 & 76.3 & 74.5 & 79.5 & 64 & $\mathbf{7 4 . 7}$ \\
\hline $\begin{array}{c}\text { Percentage } \\
\text { Increase } \\
\text { From Stage } \\
\text { 1 to 2 }\end{array}$ & $\mathbf{1 8 . 7}$ & $\mathbf{3 . 4}$ & $\mathbf{1 5 . 8}$ & $\mathbf{0 . 5}$ & $\mathbf{2 0 . 2}$ & $\mathbf{1 0 . 7}$ & $\mathbf{6}$ & $\mathbf{1 0 . 3}$ & $\mathbf{1 0 . 7}$ \\
\hline $\begin{array}{c}\text { Mean (\%) } \\
\text { for Stage 3 }\end{array}$ & 93.2 & 77.9 & 82.1 & 82.3 & 78.2 & 79.1 & 79.8 & $\mathbf{7 5 . 1}$ & $\mathbf{8 1 . 3}$ \\
\hline $\begin{array}{c}\text { Percentage } \\
\text { Increase } \\
\text { From Stage } \\
\text { 2 to 3 }\end{array}$ & $\mathbf{6 . 1}$ & $\mathbf{1 2 . 3}$ & $\mathbf{1 4 . 4}$ & $\mathbf{1 1 . 4}$ & $\mathbf{4 . 6}$ & $\mathbf{7 . 3}$ & $\mathbf{- 0 . 3}$ & $\mathbf{1 8 . 2}$ & $\mathbf{8 . 8}$ \\
\hline
\end{tabular}

It can be seen that these students' scores gradually improved from stages 0 to 3 . The

highest percentage increase was from stages 0 to 1 . This might be an indicator that a positive change occurred in the students' mathematics knowledge during the first month of the course.

\section{Figure 4}

Level quiz scores (\%) for all students participating in the study. 


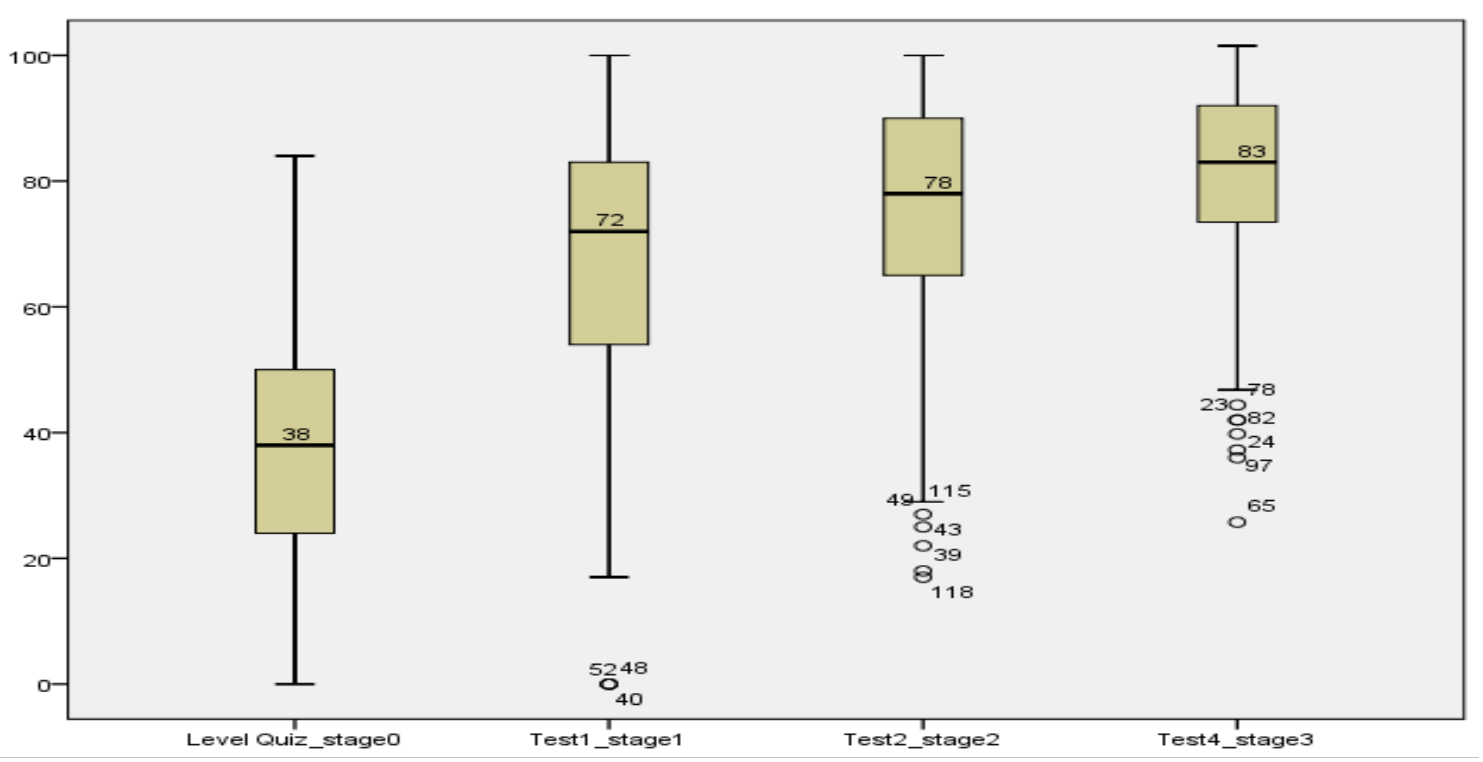

Figure 4 shows that the ranges of the test scores decreased from stages 0 to 3 and the medians increased. Not only does the increasing mean indicate better understanding but the decreasing variations support this.

\section{Correlations}

\section{Students' Self-Efficacy and Test Scores}

Statistical Package for Social Sciences (SPSS) was used to analyze the numeric data in this study.

\section{Table 6}

Pearson Correlation between students' self-efficacy and their test scores.

\begin{tabular}{|l|l|r|r|}
\hline \multicolumn{3}{|c|}{ Correlations } \\
\hline \multicolumn{2}{|c|}{} & $\begin{array}{c}\text { All S.E. } \\
\text { Total Scores } \\
(\%)\end{array}$ & $\begin{array}{c}\text { All Test } \\
\text { Scores (\%) }\end{array}$ \\
\hline $\begin{array}{l}\text { All S.E. Total Scores } \\
(\%)\end{array}$ & $\begin{array}{l}\text { Pearson } \\
\text { Correlation }\end{array}$ & & $.654^{* *}$ \\
\cline { 2 - 4 } & Sig. (2-tailed) & & .000 \\
\cline { 2 - 4 } & N & 520 & 520 \\
\hline
\end{tabular}




\begin{tabular}{|l|l|r|r|}
\hline All Test Scores (\%) & $\begin{array}{l}\text { Pearson } \\
\text { Correlation }\end{array}$ & $.654^{* *}$ & 1 \\
\cline { 2 - 4 } & Sig. (2-tailed) & .000 & \\
\cline { 2 - 4 } & N & 520 & 520 \\
\hline
\end{tabular}

**. Correlation is significant at the 0.01 level (2-tailed).

The table shows PEARSON Correlation was conducted in the study which reflected a $65 \%$ noticeable positive correlation between students' self-efficacy and test scores during the study.

Students' Motivation and Test Scores

Table 7

Pearson Correlation between students' motivation and their test scores.

\begin{tabular}{|c|c|c|c|}
\hline \multicolumn{4}{|c|}{ Correlations } \\
\hline & & $\begin{array}{c}\text { All MT. } \\
\text { Total scores } \\
(\%)\end{array}$ & $\begin{array}{c}\text { All Test } \\
\text { Scores }(\%)\end{array}$ \\
\hline \multirow[t]{3}{*}{$\begin{array}{l}\text { All MT. Total scores } \\
(\%)\end{array}$} & $\begin{array}{l}\text { Pearson } \\
\text { Correlation }\end{array}$ & 1 & $.684^{* *}$ \\
\hline & Sig. (2-tailed) & & .000 \\
\hline & $\mathrm{N}$ & 520 & 520 \\
\hline \multirow[t]{3}{*}{ All Test Scores (\%) } & $\begin{array}{l}\text { Pearson } \\
\text { Correlation } \\
\end{array}$ & $.684^{* *}$ & 1 \\
\hline & Sig. (2-tailed) & .000 & \\
\hline & $\mathrm{N}$ & 520 & 520 \\
\hline
\end{tabular}

**. Correlation is significant at the 0.01 level (2-tailed).

The table shows PEARSON Correlation was conducted in the study. It reflected a $68 \%$ noticeable positive correlation between students' motivation and test scores during the study.

\section{Success Rate}

Table 8 shows the pass-fail rates for each participating group included in the study. The codes used in the table were $\mathrm{P}=$ Pass, $\mathrm{NP}=$ Not Pass, and $\mathrm{W}=$ Withdrawn. Also, Table 9 compares the pass-fail rates for MFU students compared to the rates of the participating students in the study. 
Table 8

Pass-Fail rates for each participating group in the study.

\begin{tabular}{|c|c|c|c|c|}
\hline Group \# & Number of P & Number of NP & P (\%) & NP (\%) \\
\hline 1 & 10 & 0 & 100 & 0.0 \\
\hline 2 & 16 & 3 & 84.2 & 15.8 \\
\hline 3 & 15 & 2 & 88.2 & 11.8 \\
\hline 4 & 18 & 2 & 90.0 & 10.0 \\
\hline 5 & 12 & 2 & 85.7 & 14.3 \\
\hline 6 & 16 & 2 & 88.9 & 11.1 \\
\hline 7 & 17 & 2 & 89.5 & 10.5 \\
\hline 8 & 11 & 2 & 84.6 & 15.4 \\
\hline $\begin{array}{l}\text { Average of } \\
\text { All Groups }\end{array}$ & $\mathbf{1 4 . 4}$ & $\mathbf{1 . 9}$ & $\mathbf{8 8 . 9}$ & $\mathbf{1 1 . 1}$ \\
\hline
\end{tabular}

\section{Table 9}

Pass rates for the participating students in the study compared to all Math 096 students in MFU.

\begin{tabular}{|c|c|c|c|c|}
\hline $\begin{array}{c}\text { Academic } \\
\text { Status }\end{array}$ & $\begin{array}{c}\text { Number of Math } \\
\text { 096 Students in } \\
\text { The Study-Two } \\
\text { Cohorts }\end{array}$ & $\begin{array}{c}\text { Pass Rate for } \\
\text { The Students } \\
\text { in The Study }\end{array}$ & $\begin{array}{c}\text { Number of } \\
\text { Math 096 } \\
\text { Students in } \\
\text { MFU-Two } \\
\text { cohorts }\end{array}$ & $\begin{array}{c}\text { Pass Rate for } \\
\text { The Students } \\
\text { in MFU }\end{array}$ \\
\hline P & 115 & 88.5 & 384 & 75.4 \\
\hline NP & 15 & 11.5 & 125 & 24.6 \\
\hline Total & 130 & 100.0 & 509 & 100.0 \\
\hline
\end{tabular}

Tables 9 shows that the passing rates for the students in the target or treatment groupare higher than the passing rate of students in MFU. This reflects that the students in the target or treatment group were exposed to different approaches than the rest of Math 096 students in MFU. This might mean that implementing SMC framework in the study positively influenced the students' success rates and achievement.

\section{Discussion of Findings}




\section{Is There Any Relationship Between Students' Self-Efficacy and Their Mathematics Achievement in This Study?}

The teacher implemented the educational approaches contained in the SMC framework during the course. Most of the students participating in the study indicated that they had never been exposed to those educational approaches during their school education years. Furthermore, in their interviews, the students described how the use of each of those approaches helped to improve their self-efficacy levels and their achievement in the course. For example, Mariam described that

"The more I attended, the more I learned mathematics, the more games and puzzles we played, the more grades I gained, the more I felt that I was capable to prepare for college algebra and any future course" (Mariam).

For middle- and low-achieving students (the majority of the number of students participating in the study), not only did the findings of the study show improvement in their mathematics self-efficacy and test scores, but it also suggested that the students' self-efficacy was positively correlated to their performances in tests and final course achievements. This agrees with previous research (e.g., Williams \& Williams, 2010; Hackett, 1985; Pajares \& Miller, 1994; Pajares, 1996; Pietsch, Walker, \& Chapman, 2003) which explained that selfefficacy can influence students' performance. Most of those researchers referred to students' mathematics self-efficacy at school levels and for different western cultures. The evidence added in this study is that there is a positive correlation between college students' mathematics selfefficacy and their mathematics achievement.

Higher achievers (the minority of students in the target or treatment group) had higher self-efficacy at the start of this study. They maintained their high self-efficacy and challenged 
their knowledge and worked hard during the course to improve their knowledge and pass the course.

\section{Is There Any Relationship Between Students' Motivation And Their Mathematics Achievement In This Study?}

The researcher used the SMC framework during the course to improve students' motivation. In their interviews, the students described how the use of each of those approaches helped to improve their motivation levels. For example, Shamar explained that

"what you brought to the course has been motivating, and life-changing which I feel the most we needed at any foundation course" (Shamar).

Considering the data analysis discussed earlier, students started with low motivation levels which gradually improved from stage 0 to 3 . Considering the SMC framework approaches, the students were intrinsically motivated to play Kahoot or the Puzzle sheets. Anin illuminated that "I never played the puzzle sheets, and Kahoot before taking this course. They were so much fun and beneficial. All this taught us the main concepts of the course, motivated us to continue and made us feel better and better about the way we understood things and how can we learn maths in the future" (Anin).

Also, the students were extrinsically motivated when they gained the bonus marks, completed their online homework, and gained their assigned grades for it. Rhodhan explained that

"The bonus marks encouraged us to study more. When I receive the bonus mark, I feel motivated to work harder, understand better, and gain the grade again in the next game. This makes me feel that I can do maths and can do the next problem". 
According to the findings of this study, there was a positive correlation between students' motivation levels and their test scores. The findings supported the results discussed by researchers such as Fan and Wolters (2014) and Kim and Keller (2010) who added that students' intrinsic values positively predict their motivation and mathematics achievement. Also, other researchers such as Murayama, Pekrun, Lichtenfeld, and Hofe (2013) described that "learning strategies are described as planned sets of coordinated study tactics that are directed by a learning goal and aim to acquire a new skill or gain understanding (Alexander \& Murphy, 1998). According to these views, motivation and learning strategies should, by their nature, facilitate long-term learning processes" (2013, p. 1487).

The evidence added in this study is that there is a positive correlation between college students' motivation levels and mathematics achievement.

\section{What Features Within the Framework Promoted Improved Students' Self-Efficacy and Motivation?}

This study is unique as it explores the mathematics self-efficacy improvement in the context of a college-level course in Kuwait, especially since self-efficacy has not been a popular research topic in the Middle East. The answer to this research question came mainly through the interviews. In their interviews, students expressed their thoughts and feelings about the elements of SMC they experienced in this research and how they influenced their mathematics selfefficacy, motivation, and overall achievement. They explained what improved their engagement, learning strategies, and understanding in the classroom after being exposed to those approaches.

All the elements of SMC played a role in promoting students' self-efficacy and motivation, some more than others and some combined with others. This section presents 
evidence of the influence of each element, starting with those most appreciated by the students, based on the analysis of their interviews. The transcribed and coded interviews were analyzed and ranked based on the approaches that most students talked about. The ranking reflected the number count for each approach towards students' self-efficacy and motivation. This showed that teacher's teaching methodology, group work, teacher's attitude, and gamification were the most influential approaches according to students' interviews and recommendations.

Different researchers indicated that teacher's teaching methodology promoted selfefficacy (Brookfield, 2011; Çelik, 2019; Damrongpanit, 2019; Hamurcu \& Canbulat, 2019) and motivation (Barnes, 2005; Peled \& Segalis, 2005). This is confirmed by this study according to Amna who clarified that

"I can easily do mathematics and I like doing it. Everything you offered us in class, the way you teach, the way you ask us and discuss different problems, and how you go around us. What we have done in this course is so different from all the mathematics courses I took before. This prepared me properly to take any course in the future as I am capable to learn. I wish other teachers learn from you." (Amna)

Other researchers indicated that teacher's attitude positively influenced students' selfefficacy (Gudek, 2019; Engin, 2020; Fadhila, Ridlo, \& Indriyanti, 2020; Wahyudiati \& Rohaeti, 2020) and motivation (Fan \& Wolters, 2014). This has also been confirmed by this study, as the following interview extract shows.

“It's amazing the influence of 'do this', 'follow this', 'pay attention', 'don't forget to do your homework on daily basis at a certain time', 'why did you do this in the quiz?' when you schedule to meet us in your office. All this seriously made me 
learn how to learn properly, how to organize my time, and motivated me to work harder in the course. It showed me that I can do it, I can learn mathematics and pass." (Bojbarah)

Students appreciated the benefits of using group work and how this assisted their progress in learning mathematics during the course. Also, using group work motivated them to work harder and learn more. Mariam expressed her opinion and said that:

“Group work was a motivating method to learn in class. Sometimes If I don't understand anything through any problem, my group members will explain it to me. I love it because everyone is cooperating so that we all work hard and understand ...I understand much better and feel more confident that I can pass the course easily." (Mariam)

Using group work encouraged students to work hard with each other, bring each other to the same level of thinking, and to study together outside and inside the classroom. Using group work not only improved students' motivation (Steinberg \&Vinjamuri, 2014; Martin \& Towers, 2015; Wegerif et al., 2017), but also improved their self-efficacy as well (Chiriac, Rosander, \& Frykedal, 2019; Kopparla \& Goldsby, 2019). Group work was involved while playing the puzzle sheets, answering the revision notes, and while using different teacher's teaching methodologies. This also shows that group work can be used widely in classroom practice with a variety of activities.

Gamification was the top fourth element recommended by the students' interviews to promote students' self-efficacy during the course. This adds more evidence to what was found by researchers such as (Parker, 2006; Van Dinther, Dochy, \& Segers, 2011; Gani, 2019; Louth \& 
Jamieson-Proctor, 2019) and motivation according to Lazarides, Buchholz \& Rubach, (2017) and Topîrceanu's (2017). Saad added in this respect that

"I loved playing the puzzle sheets. I used to make sure not to miss those days because it was so much fun and we received bonus marks added to our quiz grades. This was very motivating for us to attend class more and understand more mathematics. Playing Kahoot was another motivating game the teacher used in class as we could use our mobile phones. The top 10 scoring students received the bonus mark. I liked it a lot because it helped us to improve our quiz grades and to focus on learning to solve each question faster. This made me feel that I can finally learn and understand mathematics" (Saad).

In regards to rewarding the students using bonus marks, this study confirmed the positive impact found by other studies regarding promoting self-efficacy (e.g., Park \& Yang, 2019; Zhang, Zhang, Liu, \& Du, 2019) and motivation (Miendlarzewska, Bavelier, \& Schwartz, 2016). The students in this study were grades driven. This means, the more they attended, the more bonus marks they could gain, and the better they felt about their capabilities to solve more mathematics problems. As the effectiveness of this approach depends on the success in the tasks set, it requires conditions that will increase students' engagement with the task and their motivation to work harder to complete a "success cycle" (Ernest, 2011). In other words, it requires the implementation of the other elements of SMC. Bader confirmed this by saying that "The more bonus marks I gained, the better I felt about myself, the more motivated I was to work hard and understand. This made me feel that I could solve more mathematics problems in the future" (Bader). 
Having an online interactive educational platform was another important approach the students mentioned in their interviews that promoted their self-efficacy during the course. Bojbarah clarified that

"I was not too careful to do my online homework at the early stages of the course. After using the program, I didn't accept less than 100\% in each homework section. ... I write each question down and compare it to your questions learned in class, find the solution, and enter it. It's a very good practice. It was motivating that the program compliments us saying "well done”, "fantastic”, "Keep going”. This made me feel that I can always do the next question and can improve learning the course contents" (Bojbarah).

Researchers from the literature review also confirmed that using technology programs in the educational platform can improve students' self-efficacy as well (Nordlöf, Hallström, \& Höst, 2019; O'Neil \& Krause, 2019; Bakar, Maat, \& Rosli, 2020) and motivation (Handal \& Herrington, 2003).

The next influencing approach from the SMC was the one concerning correcting students' own errors. Researchers such as Ahn, Usher, Butz, and Bong (2016) explained that positive or negative feedback through the use of social persuasion can affect students' selfefficacy. When the students realize their mistakes, understand them, and learn how to correct them, this can promote students' self-efficacy (Peranginangin, Saragih, \& Siagian, 2019; Masitoh \& Prasetyawan, 2020; Maulidia, Saminan, \& Abidin, 2020; Fitriani et al., 2020). This also can promote students' motivation (Kazemi \& Stipek, 2001; Swan, 2005). By correcting their own errors, students learned about their own learning — how they did it and how they could do it differently — which is a metacognitive thinking skill of a higher order (Smith, 2014). If 
students develop such higher-order thinking skill, then they will increase their capability of solving more complex mathematical problems by themselves. Fahad confirmed this when he clarified that

"You brought the graded tests and asked us to go over our mistakes within our groups so that we understand our mistakes and learn why did we do them. Going over my mistakes made me feel motivated to understand mathematics better than before. It made understanding mathematics seem so much easier than what I expected and that I am capable to understand mathematics in future courses" (Fahad).

Using revision notes and the small boards in the classroom although less influencing did have an impact regarding improving students' self-efficacy according to the students' reviews. Bader confirmed this when he explained that "revision notes were excellent and interesting. They showed a summary of the chapter. They helped me to understand the most important concepts covered in the chapter also using creating examples more than just solving examples. This also made me feel that I am capable to learn mathematics easily” (Bader).

Using revision notes and the small boards allowed the students to be exposed to creative learning, self-regulating skills, and better understanding and motivation respectively (Lupu, 2013) and (Hagger et al., 2016), and improved their self-efficacy (Dinther, Dochy, \& Segers, 2011). Fares confirmed this regarding using the small boards when he described their benefits that

"Using the small board was such a good daily review for yesterday's lesson. It was fun and fast. The questions reminded us of the basic information of the lesson, which built our 
confidence and knowledge, and capability well enough so that we can solve any other mathematics problems in the future courses" (Fares).

Although some of the elements appeared to have more influence than others, based on students' interviews, it was the combination of all that made the difference in students' selfefficacy, motivation, and achievement, but also in their attitudes towards the subject and the course. For example, the students realized the importance of taking this course before joining college-level courses. Hanif clarified that

"what you brought to the course has been major life-changing which I feel the most we needed at any foundation course ... it changed my mind about studying mathematics as I feel that I can take any mathematics course in the future" (Hanif). Other students like Hassan used to hate studying mathematics and they mentioned that "I used to find math very difficult to understand. I used to hate it but now it's becoming easier and I can do it" (Hassan).

\section{Limitations of The Study}

The sample size for the students participating in this study was 130 students which is considered a limitation.

The role of the researcher-teacher is considered another limitation in the study and a potential for bias. Also, to avoid biases, the study involved exploring the academic approaches in SMC in the study, reasons for finding them, and how they could influence students' mathematics achievement. The researcher kept a research journal during the study as suggested by researchers such as Watt (2007). She shared this research journal and the designed plan for the main study with her director of studies and MFU supervisors to make sure that her designed plan would not influence the routine of the course. 


\section{Conclusion}

The researcher in this study investigated students' weaknesses when they join an American foundation program at a university in Kuwait. Students' self-efficacy and motivation were significantly weak when they joined the foundation program. The researcher aimed to improve their self-efficacy, motivation, and overall performance by implementing the SMC framework. The study showed that implementing the SMC framework helped to develop students' mathematics self-efficacy and motivation, and ultimately their mathematics achievement. The study also provided more evidence for the argument about the positive correlation between selfefficacy, motivation and achievement, and overall success in mathematics learning. Consequently, the study suggests that implementing the SMC framework might be beneficial for adult students in higher mathematics courses or at the high school system. The latter is the ground for further research. This research should be a larger-scale study to examine the use and the impact of SMC more widely and under various conditions. It should involve different teachers in different learning settings, from high school to college and university, and larger and diverse student populations.

\section{References}

Accuplacer. (2015). College Board. Retrieved from http://accuplacer.collegeboard.org/students

Ahn, H. S., Usher, E. L., Butz, A., \& Bong, M. (2016). Cultural differences in the understanding of modelling and feedback as sources of self-efficacy information. British Journal of Educational Psychology, 86(1), 112-136.

Akinsola, M. K., \& Awofala, A. O. A. (2008). Effects of problem context and reasoning complexity on Mathematics problem solving achievement and transfer of Secondary School students. European Journal of Scientific Research, 20(3), 641-651. 
Anderman, E. M., \& Wolters, C. A. (2006). Goals, Values, and Affect: Influences on Student Motivation. In P. A. Alexander \& P. H. Winne (Eds.), Handbook of educational psychology (p. 369-389). Lawrence Erlbaum Associates Publishers.Bakar, N. S. A., Maat, S. M., \& Rosli, R. (2020). Mathematics Teacher's Self-efficacy of Technology Integration and Technological Pedagogical Content Knowledge. Journal on Mathematics Education, 11(2), 259-276.

Bandura, A. (1977). Self-efficacy: toward a unifying theory of behavioral change. Psychological review, 84(2), 191.

Banerjee, R., \& Subramaniam, K. (2012). Evolution of a teaching approach for beginning algebra. Educational Studies in Mathematics, 80(3), 351-367.

Barnes, H. (2005). The theory of Realistic Mathematics Education as a theoretical framework for teaching low attainers in mathematics. Pythagoras, (61), 42-57.

Bong, M. (1999). Personal factors affecting the generality of academic self-efficacy judgments: Gender, ethnicity, and relative expertise. The Journal of Experimental Education, 67(4), 315-331.

Brookfield, S. D. (2011). Teaching for critical thinking: Tools and techniques to help students question their assumptions. John Wiley \& Sons.

Chambers, P., \& Timlin, R. (2013). Teaching mathematics in the secondary school. Sage.

Chemers, M. M., Hu, L. T., \& Garcia, B. F. (2001). Academic self-efficacy and first year college student performance and adjustment. Journal of Educational psychology, 93(1), 55.

Cheng, Y. S. (2001). Learners. Concentric: Studies in Linguistics, 27(2), 75-90. 
Chiriac, E. H., Rosander, M., \& Frykedal, K. F. (2019). An Educational Intervention to Increase Efficacy and Interdependence in Group Work. Education Quarterly Reviews, 2(2).

Çelik, F. (2019). The Effect of Outcomes in The Teaching Principles and Methods Course in The Pedagogical Formation Program on Prospective Teachers' Self-efficacy Beliefs. European Journal of Education Studies.

Cruickshank, D. R., \& Telfer, R. (1980). Classroom games and simulations. Theory into practice, $19(1), 75-80$.

Damrongpanit, S. (2019). From Modern Teaching to Mathematics Achievement: The Mediating Role of Mathematics Attitude, Achievement Motivation, and Self-Efficacy. European Journal of Educational Research, 8(3), 713-727.

Duda, J. L., \& Nicholls, J. G. (1992). Dimensions of achievement motivation in schoolwork and sport. Journal of educational psychology, 84(3), 290.

Engin, G. (2020). An Examination of Primary School Students' Academic Achievements and Motivation in Terms of Parents' Attitudes, Teacher Motivation, Teacher Self-Efficacy and Leadership Approach. International Journal of Progressive Education, 16(1), 257276.

Ernest, P. (2011). The psychology of learning mathematics: the cognitive, affective and contextual domains of mathematics education. Ssarbrucken, Germany: LAP LAMBERT. Academic Publishing.

Fadhila, F., Ridlo, S., \& Indriyanti, D. R. (2020). Analysis of Learning Implementation, SelfEfficacy, and Students Attitude Towards Science in Relation with Science Literacy. Journal of Innovative Science Education, 9(2), 288-294. 
Fan, W., \& Wolters, C. A. (2014). School motivation and high school dropout: The mediating role of educational expectation. British journal of educational psychology, 84(1), 22-39.

Ferla, J., Valcke, M., \& Cai, Y. (2009). Academic self-efficacy and academic self-concept: Reconsidering structural relationships. Learning and Individual Differences, 19(4), 499-505.

Flavell, J. H. (1976). Metacognitive aspects of problem solving. In L. B. Resnick (Ed.) The nature of intelligence, pp.231-236. Erlbaum.

Gani, H. R. A. (2019). The Use of Team Game Tournament to Improve Students'elt Classroom Interaction and Reading Comprehension in Relation to Self-efficacy. Jo-ELT (Journal of English Language Teaching) Fakultas Pendidikan Bahasa \& Seni Prodi Pendidikan Bahasa Inggris IKIP, 6(2), 84-90. Githua, B. N., \& Mwangi, J. G. (2003). Students' mathematics self-concept and motivation to learn mathematics: relationship and gender differences among Kenya's secondary school students in Nairobi and Rift Valley provinces. International Journal of Educational Development, 23(5), 487-499.

Gredler, M. E., Broussard, S. C. and Garrison, M. E. B. (2004). The relationship between classroom motivation and academic achievement in elementary schoolaged children. Family and Consumer Sciences Research Journal, 33(2), 106-120.

Guay, F., Chanal, J., Ratelle, C. F., Marsh, H. W., Larose, S., \& Boivin, M. (2010). Intrinsic, identified, and controlled types of motivation for school subjects in young elementary school children. British Journal of Educational Psychology, 80(4), 711-735. 
Gudek, B. (2019). Computer Self-Efficacy Perceptions of Music Teacher Candidates and Their Attitudes towards Digital Technology. European Journal of Educational Research, 8(3), 683-696.

Hackett, G. (1985). Role of mathematics self-efficacy in the choice of math-related majors of college women and men: A path analysis. Journal of counseling psychology, 32(1), 47.

Hagger, M. S., Sultan, S., Hardcastle, S. J., Reeve, J., Patall, E. A., Fraser, B.\& Chatzisarantis, N. L. (2016). Applying the integrated trans-contextual model to mathematics activities in the classroom and homework behavior and attainment. Learning and Individual Differences, 45, 166-175.

Hall, A. B. (2019). Personalized Professional Learning Experiences and Teacher Self-Efficacy for Integrating Technology in K-12 Classrooms.

Hamurcu, H., \& Canbulat, T. (2019). Preservice Teachers' Perceived Self-Efficacy in Selection of Teaching Methods and Techniques.

Handal, B., \& Herrington, A. (2003). Re-examining categories of computer-based learning in mathematics education. Contemporary Issues in Technology and Teacher Education, 3(3), 275-287.

Hargreaves, M., Shorrocks-Taylor, D., Swinnerton, B., Tait, K., \& Threlfall J. (2004). Computer or paper/ That is the question; does the medium in which assessment questions are presented affect children's performance in mathematics? Educational Research, 46, 2942.

Hoffman, B. (2010). "I think I can, but I'm afraid to try": The role of self-efficacy beliefs and mathematics anxiety in mathematics problem-solving efficiency. Learning and individual differences, 20(3), 276-283. 
KAHOOT (2018). Retrieved from https://create.kahoot.it/login

Kazemi, E., \& Stipek, D. (2001). Promoting conceptual thinking in four upper-elementary mathematics classrooms. Elementary School Journal, 102, 59-80.

Kim, C., \& Keller, J. M. (2010). Motivation, volition and belief change strategies to improve mathematics learning. Journal of Computer Assisted Learning, 26(5), 407-420.

Kitsantas, A., Cheema, J., \& Ware, H. W. (2011). Mathematics achievement: The role of homework and self-efficacy beliefs. Journal of Advanced Academics, 22(2), 310-339.

Kopparla, M., \& Goldsby, D. (2019). Preservice Teacher Experiences in Formal and Informal Cooperative Learning Groups in A Mathematics Course. Journal of Instructional Research $\mid$ Volume, 8(1), 52.

Lazarides, R., Buchholz, J., \& Rubach, C. (2017). Teacher enthusiasm and self-efficacy, studentperceived mastery goal orientation, and student motivation in mathematics classrooms. Teaching and Teacher Education, 69, 1-10.

Liu, X., \& Koirala, H. (2009). The effect of mathematics self-efficacy on mathematics achievement of high school students.

Lupu, C. (2013). Use of mathematical content sheets. Procedia-Social and Behavioral Sciences, 93, 1673-1680.

Martin, L. C., \& Towers, J. (2015). Growing mathematical understanding through collective image making, collective image having, and collective property noticing. Educational Studies in Mathematics, 88(1), 3-18.

Mason, J. (2002). Minding your Qs and Rs: Effective questioning and responding in the mathematics classroom. Aspects of teaching secondary mathematics: Perspectives on practice, $248-258$. 
Miendlarzewska, E. A., Bavelier, D., \& Schwartz, S. (2016). Influence of reward motivation on human declarative memory. Neuroscience \& Biobehavioral Reviews, 61, 156-176.

Mitcham, M., Greenidge, W. L., Bradham-Cousar, M., Figliozzi, J., \& Thompson, M. A. (2012). Increasing Career Self-Efficacy Through Group Work With Culturally and Linguistically Diverse Students. Journal of School Counseling, 10(22), n22.

Murayama, K., Pekrun, R., Lichtenfeld, S., \& Vom Hofe, R. (2013). Predicting long-term growth in students' mathematics achievement: The unique contributions of motivation and cognitive strategies. Child development, 84(4), 1475-1490.

Nordlöf, C., Hallström, J., \& Höst, G. E. (2019). Self-efficacy or context dependency?: Exploring teachers' perceptions of and attitudes towards technology education. International Journal of Technology and Design Education, 29(1), 123-141.

O'Neil, K., \& Krause, J. M. (2019). Physical education teacher education faculty self-efficacy toward educational technology. The Physical Educator, 76(5).

Pajares, F. (1996). Self-efficacy beliefs in academic settings. Review of Educational Research, $66,543-578$

Pajares, F., \& Miller, M. D. (1994). Role of self-efficacy and self-concept beliefs in mathematical problem solving: A path analysis. Journal of educational psychology, 86(2), 193.

Park, J., \& Yang, J. S. (2019). Moderating Effects of the Timing of Reward Determination and Performance Standards between Rewards and Self-Efficacy for Sustainable Intrinsic Motivation. Sustainability, 11(17), 4619.

Parker, J. (2006). Developing perceptions of competence during practice learning. British Journal of Social Work, 36, 1017-1036 
Peled, I., \& Segalis, B. (2005). It's not too late to conceptualize: Constructing a generalized subtraction schema by abstracting and connecting procedures. Mathematical Thinking and Learning, 7(3), 207-230.

Pietsch, J., Walker, R., \& Chapman, E. (2003). The relationship among self-concept, selfefficacy, and performance in mathematics during secondary school. Journal of educational psychology, 95(3), 589.

Pintrich, P. R. (1991). A manual for the use of the Motivated Strategies for Learning Questionnaire (MSLQ).

Rahimi, A., \& Abedini, A. (2009). The interface between EFL learners' self-efficacy concerning listening comprehension and listening proficiency. Novitas-Royal, 3(1), $14-28$.

Robbins, S. B., Allen, J., Casillas, A., Peterson, C. H., \& Le, H. (2006). Unraveling the different effects of motivational and skills, social, and self-management measures from traditional predictors of college outcomes. Journal of Educational Psychology, 98, 598-616.

Rowe, J. (2001). An experiment in the use of games in the teaching of mental arithmetic. Philosophy of Mathematics Education, 14, 1-23.

Sansone, C., \& Harackiewicz, J. M. (Eds.). (2000). Intrinsic and extrinsic motivation: The search for optimal motivation and performance. Elsevier.

Schoenfeld, A. H. (1992). Learning to think mathematically: Problem solving, metacognition and sense-making in mathematics. In D. A. Grouws \& National Council of Teachers of Mathematics (Eds.), Handbook of research on mathematics teaching and learning (pp. 334-370). Macmillan. 
Siegle, D., \& McCoach, D. B. (2007). Increasing student mathematics self-efficacy through teacher training. Journal of Advanced Academics, 18(2), 278-312.

Skaalvik, E. M., \& Valås, H. (1999). Relations among achievement, self-concept, and motivation in mathematics and language arts: A longitudinal study. The Journal of Experimental Education, 67(2), 135-149.

Smith, R. O. (2014). Beyond passive learning: Problem-based learning and concept maps to promote basic and higher-order thinking in basic skills instruction. Journal of Research and Practice for Adult Literacy, Secondary, and Basic Education, 3(2), 50-55.

Sokol, A., Gozdek, A., \& Figurska, I. (2015). The importance of teacher leadership in shaping the creative attitudes of students. Procedia-Social and Behavioral Sciences, 197, 19761982.

Soliman, M., \& Hilal, A. (2016). Investigating the effects of Computer-Assisted Instruction on Achievement and Attitudes towards Mathematics Among Seventh-Grade Students in Kuwait. International Journal of Technology in Mathematics Education, 23(4), 145-160.

Stirin Tzur, K., Ganzach, Y., \& Pazy, A. (2016). On the positive and negative effects of selfefficacy on performance: Reward as a moderator. Human Performance, 29(5), 362-377.

Steinberg, D. M., \& Vinjamuri, M. K. (2014). Activating Adult-Learning Principles Through Small Groups in Preparing Social Work Students to Achieve CSWE Research Competencies. Journal of Teaching in Social Work, 34(4), 363-383.

Sundre, D., Barry, C., Gynnild, V., \& Ostgard, E. T. (2012). Motivation for achievement and attitudes toward mathematics instruction in a required calculus course at the Norwegian University of Science and Technology.Numeracy, 5(1), 4.

Swan, M. (2005). Standards Unit-Improving learning in mathematics: challenges and strategies. 
Topîrceanu, A. (2017). Gamified learning: A role-playing approach to increase student in-class motivation. Procedia Computer Science, 112, 41-50.

Ünlü, M., Avcu, S., \& Avcu, R. (2010). The relationship between geometry attitudes and selfefficacy beliefs towards geometry. Procedia-Social and Behavioral Sciences, 9, 1325-

1329.Usher, E. L. (2009). Sources of middle school students' self-efficacy in mathematics: A qualitative investigation. American Educational Research Journal, 46(1), 275-314.

Van Dinther, M., Dochy, F., \& Segers, M. (2011). Factors affecting students' self-efficacy in higher education. Educational research review, 6(2), 95-108.

Wahyudiati, D., \& Rohaeti, E. (2020). Attitudes toward Chemistry, Self-Efficacy, and Learning Experiences of Pre-Service Chemistry Teachers: Grade Level and Gender Differences. International Journal of Instruction, 13(1), 235-254.

Watt, D. (2007). On becoming a qualitative researcher: the value of reflexivity. Qualitative Report, 12(1), 82-101.

Wegerif, R., Fujita, T., Doney, J., Linares, J. P., Richards, A., \& Van Rhyn, C. (2017). Developing and trialing a measure of group thinking. Learning and Instruction, 48, 4050.

Wigfield, A., \& Eccles, J. S. (2000). Expectancy-value theory of achievement motivation. Contemporary educational psychology, 25(1), 68-81.

Williams, T., \& Williams, K. (2010). Self-efficacy and performance in mathematics: Reciprocal determinism in 33 nations. Journal of educational Psychology, 102(2), 453.

Wyatt, M. (2010). An English teacher's developing self-efficacy beliefs in using group work. System, 38(4), 603-613. 
Yeh, Y. C., Chen, S. Y. C., Rega, E. M. R., \& Lin, C. S. L. (2019). Mindful learning experience facilitates mastery experience through heightened flow and self-efficacy in game-based creativity learning. Frontiers in psychology, 10, 1593.

Yin, R. K. (2014). Case study research: design and methods 5th ed. Thousand Oaks.

Zerpa, C., Hachey, K., van Barneveld, C., \& Simon, M. (2011). Modeling student motivation and students' ability estimates from a large-scale assessment of mathematics. Sage Open, 1(2), 2158244011421803.

Zhang, D., Zhang, F., Liu, S., \& Du, H. S. (2019). Impact of referral reward program on innovative customers' follow-up e-referral. Information Technology \& People.

Zimmermann, M., Bescherer, C., \& Spannagel, C. (2011). A questionnaire for surveying mathematics self-efficacy expectations of future teachers. Article of German Federal Ministry of Education and Research.

\section{Appendix A: \\ Student's Background, Self-efficacy and Motivation questionnaires \\ Towards Studying Mathematics at MFU, at (NAME WAS REMOVED FOR THE PEER REVIEW).}

\section{A: Student's Mathematics Background}

Please read the questions carefully before you decide to participate in the study. Respond to each statement using the scale provided below:

Choose Yes or No for the questions 1 to 11:

\begin{tabular}{|c|c|c|}
\hline Statement & Yes & No \\
\hline 1. I graduated with an Arts major high school diploma. & Yes & No \\
\hline
\end{tabular}




\begin{tabular}{|c|c|c|}
\hline $\begin{array}{l}\text { 2. I graduated with a Science major high school diploma. } \\
\text { If other diploma program, please list below: }\end{array}$ & Yes & No \\
\hline $\begin{array}{l}\text { 3. Below is the highest mathematics course I received in } \\
\text { my high school diploma, (choose one): } \\
\text { Algebra I (Grade } 8 \text { mathematics) } \\
\text { Algebra II (Grade } 9 \text { or } 10 \text { mathematics) } \\
\text { Pre-Calculus (Grade } 11 \text { mathematics) } \\
\text { Calculus (Grade } 12 \text { mathematics) }\end{array}$ & & \\
\hline $\begin{array}{l}\text { 4. I took the course Math } 095 \text { here at (NAME WAS } \\
\text { REMOVED FOR THE PEER REVIEW). } \\
\text { 5. If yes, how many time? }\end{array}$ & Yes & No \\
\hline 6. I am taking Math 096 for the first time. & Yes & No \\
\hline 7. I am taking Math 096 for the second time or more. & Yes & No \\
\hline $\begin{array}{l}\text { 8. Mathematics was my favourite subject taken during my } \\
\text { high school diploma. }\end{array}$ & Yes & No \\
\hline $\begin{array}{l}\text { 9. I cannot solve any mathematics problem without the } \\
\text { help of a calculator. }\end{array}$ & Yes & No \\
\hline $\begin{array}{l}\text { 10. I believe it is important for me to take a foundation } \\
\text { mathematics course before joining the academic } \\
\text { program at (NAME WAS REMOVED FOR THE PEER } \\
\text { REVIEW). }\end{array}$ & Yes & No \\
\hline $\begin{array}{l}\text { 11. I enjoy using different computing programs when } \\
\text { solving an algebraic problem. }\end{array}$ & Yes & No \\
\hline
\end{tabular}

\section{B: Self-efficacy belief towards studying mathematics at MFU?}

Please respond to each statement using the scale provided below:

SD: I strongly disagree

D: I disagree

$\mathrm{N}$ : I neither agree nor disagree

A: I agree

SA: I strongly agree 


\begin{tabular}{|c|c|c|c|c|c|}
\hline $\begin{array}{l}\text { 1. I am confident that I can understand the basic } \\
\text { algebraic concepts presented by the instructor in this } \\
\text { course. }\end{array}$ & SD & D & $\mathbf{N}$ & $\mathbf{A}$ & SA \\
\hline $\begin{array}{l}\text { 2. I am confident that I can understand the most } \\
\text { complicated algebraic concepts presented by the } \\
\text { instructor in this course. }\end{array}$ & SD & D & $\mathbf{N}$ & A & SA \\
\hline $\begin{array}{l}\text { 3. I am confident that I can do a great job in my } \\
\text { mathematics and algebraic assignments }\end{array}$ & SD & D & $\mathbf{N}$ & A & SA \\
\hline $\begin{array}{l}\text { 4. I am confident I can perform well in the quizzes and } \\
\text { tests offered in this course. }\end{array}$ & SD & D & $\mathbf{N}$ & A & SA \\
\hline $\begin{array}{l}\text { 5. I am certain that I can read and solve the hardest } \\
\text { word problems and applications taught in this course. }\end{array}$ & SD & D & $\mathbf{N}$ & A & SA \\
\hline $\begin{array}{l}\text { 6. I am certain that I can master the skills being taught } \\
\text { in this course. }\end{array}$ & SD & D & $\mathbf{N}$ & A & SA \\
\hline $\begin{array}{l}\text { 7. I am confident I can solve any type of mathematics or } \\
\text { algebraic question in this course without the use of } \\
\text { the calculator. }\end{array}$ & SD & D & $\mathbf{N}$ & A & SA \\
\hline $\begin{array}{l}\text { 8. Considering the difficulty of this course, the } \\
\text { instructor, and my skills, I think I will improve my } \\
\text { mathematics understanding in this course. }\end{array}$ & SD & D & $\mathbf{N}$ & A & SA \\
\hline $\begin{array}{l}\text { 9. I am confident that receiving a high grade on my } \\
\text { Algebraic test will encourage me to study harder for } \\
\text { the following quiz or test. }\end{array}$ & SD & D & $\mathbf{N}$ & $\mathbf{A}$ & SA \\
\hline $\begin{array}{l}\text { 10. The harder the mathematics problem is, the more } \\
\text { confident and challenged I am to solve it. }\end{array}$ & SD & D & $\mathbf{N}$ & $\mathbf{A}$ & SA \\
\hline $\begin{array}{l}\text { 11. I am confident that I am capable of learning } \\
\text { mathematics and Algebra in this course. }\end{array}$ & SD & D & $\mathbf{N}$ & $\mathbf{A}$ & SA \\
\hline 12. I am certain that I will pass this course. & SD & D & $\mathbf{N}$ & $\mathbf{A}$ & SA \\
\hline $\begin{array}{l}\text { 13. I am confident that I will pass the next mathematics } \\
\text { or algebraic course needed for my college major. }\end{array}$ & SD & D & $\mathbf{N}$ & $\mathbf{A}$ & SA \\
\hline $\begin{array}{l}\text { 14. I am certain I have the talent to successfully complete } \\
\text { mathematics course. }\end{array}$ & SD & D & $\mathbf{N}$ & $\mathbf{A}$ & SA \\
\hline
\end{tabular}

\section{Motivation towards studying mathematics at MFU?}

Please respond to each statement using the scale provided below:

SD: I strongly disagree

D: I disagree

$\mathrm{N}$ : I neither agree nor disagree

A: I agree

SA: I strongly agree 


\begin{tabular}{|c|c|c|c|c|c|}
\hline $\begin{array}{l}\text { 1. I feel that I will be able to use what I learn in this } \\
\text { course in other courses. }\end{array}$ & SD & D & $\mathbf{N}$ & A & SA \\
\hline $\begin{array}{l}\text { 2. Getting a good grade in this course motivates me to } \\
\text { work harder and practice more. }\end{array}$ & SD & D & $\mathbf{N}$ & A & SA \\
\hline $\begin{array}{l}\text { 3. I feel that if I try hard enough, then I will } \\
\text { understand the course materials. }\end{array}$ & SD & D & $\mathbf{N}$ & A & SA \\
\hline $\begin{array}{l}\text { 4. I want to do well in this course because it is } \\
\text { important to show my ability to my family, friends, } \\
\text { employer, or others. }\end{array}$ & SD & D & $\mathbf{N}$ & A & SA \\
\hline 5. I expect to do well in this course. & SD & D & $\mathbf{N}$ & A & SA \\
\hline $\begin{array}{l}\text { 6. I feel that mathematics is becoming an easier subject } \\
\text { to learn. }\end{array}$ & SD & D & $\mathbf{N}$ & $\mathbf{A}$ & SA \\
\hline $\begin{array}{l}\text { 7. I feel that something I learn in mathematics makes } \\
\text { me think about things. }\end{array}$ & SD & D & $\mathbf{N}$ & $\mathbf{A}$ & SA \\
\hline $\begin{array}{l}\text { 8. In this course, I feel that I learn something } \\
\text { interesting }\end{array}$ & SD & D & $\mathbf{N}$ & $\mathbf{A}$ & SA \\
\hline $\begin{array}{l}\text { 9. Learning mathematics gives me opportunities for } \\
\text { personal advancement. }\end{array}$ & SD & D & $\mathbf{N}$ & $\mathbf{A}$ & SA \\
\hline $\begin{array}{l}\text { 10. I expect to be able to solve mathematical problems } \\
\text { anywhere I come across them if they are of my level } \\
\text { of education. }\end{array}$ & SD & D & $\mathbf{N}$ & $\mathbf{A}$ & SA \\
\hline
\end{tabular}

